\title{
Manipulating the nervous system: The brave new world
}

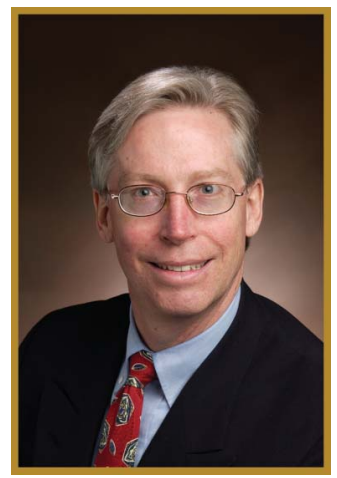

W

hen those of us with a little gray hair (OK, a lot of gray hair) were in training, a common disparaging refrain among those who deigned to enter

fields other than neurology was that neurology was the field of "diagnose and adios." For much of the history of the discipline, this was likely a fair criticism. For many years, neurologists have had techniques available to measure electrical output, e.g., EEG, EMG, and evoked potentials, and to image the brain and spine. Until relatively recently, however, only a small number of drugs were available that could alter the many, sometimes esoteric, diseases confronted by the neurologist. Over the last 30 years, remarkable therapies have emerged to transform a variety of neurologic maladies into treatable and manageable, if not curable, conditions. Many advances have been made in the realm of pharmacotherapy. Perhaps more remarkable is the increasing array of implantable or wearable devices that either deliver drugs directly to the brain or spine (intraventricular devices such as Ommaya reservoirs and intrathecal baclofen pumps) or that stimulate specific areas of the brain, spine, or peripheral nerves for therapeutic purposes. We have already provided updates in the use of deep brain stimulators for movement disorders and emerging devices for epilepsy. This issue of Neurology ${ }^{\circledR}$ Clinical Practice features articles on transcranial magnetic stimulation and nonmydriatic retinal photography, and over the course of coming months we will have articles on baclofen pumps, vagal nerve stimulators, functional electrical stimulators for muscle activation, spinal stimulators for pain relief, and others. In addition, we will deliver an update on the potential uses of stem cells in neurologic diseases. In a classic line from the 1994 American movie Speed, pyromaniac Howard Payne (Dennis Hopper) instructs LAPD police officer Jack Traven (Keanu Reeves) "Do not attempt to grow a brain." Too late. Even then, the first reports of neural transplants for Parkinson disease had already been reported, and numerous studies with various types of stem cells in neurologic conditions have either been completed or are under way. The development of inducible pluripotent stem cells and approaches that transplant somatic cell nuclei into oocytes should accelerate research of true neural stem cell transplants. In 
this context, I can ask only one question: why does any physician enter a field other than neurology or neurosciences?

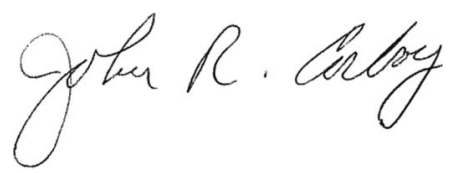

John R. Corboy, MD, FAAN

\section{Share Your Knowledge}

Neurology ${ }^{\circledR}$ Clinical Practice encourages readers to share their insights, expertise, and experiences.

- How are you employing drugs and devices in your field?

- What ethical challenges do you face?

- Do you have a case report that is illustrative of a clinical challenge?

- What challenges have you faced or successes have you enjoyed in bringing greater efficiency to your practice?

If you are interested in delivering a high-quality, peer-reviewed message to your colleagues in practice, submit your paper online. 


\title{
Neurology ${ }^{\circ}$ Clinical Practice
}

\author{
Manipulating the nervous system: The brave new world \\ John R. Corboy \\ Neurol Clin Pract 2013;3;455-456 \\ DOI 10.1212/01.CPJ.0000435750.40492.09
}

This information is current as of December 9, 2013

Updated Information \&

Services

Permissions \& Licensing

Reprints including high resolution figures, can be found at:

http://cp.neurology.org/content/3/6/455.full.html

Information about reproducing this article in parts (figures,tables) or in its entirety can be found online at:

http://cp.neurology.org/misc/about.xhtml\#permissions

Information about ordering reprints can be found online:

http://cp.neurology.org/misc/addir.xhtml\#reprintsus

Neurol Clin Pract is an official journal of the American Academy of Neurology. Published continuously since 2011, it is now a bimonthly with 6 issues per year. Copyright ( 2013 American Academy of Neurology. All rights reserved. Print ISSN: 2163-0402. Online ISSN: 2163-0933.

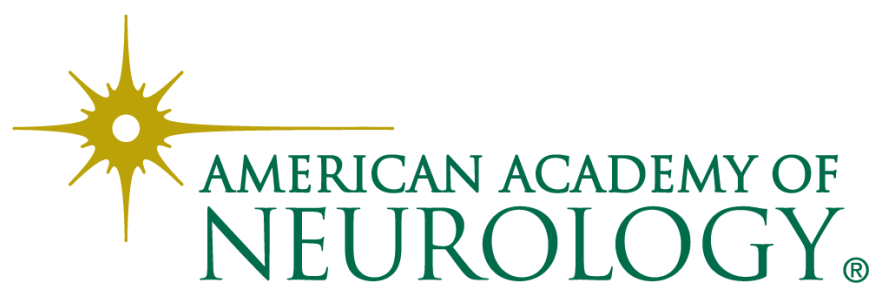

